\title{
Petrology, REE Geochemistry and Tetrad Effect of Some Muscovite Granites at Wadi El Gemal Area, South Eastern Desert, Egypt
}

\author{
Ahmed S. Shalan \\ Nuclear Materials Authority, El-Maadi, Cairo, Egypt \\ Email: dr_ahmedshalan84@yahoo.com
}

How to cite this paper: Shalan, A. S. (2022). Petrology, REE Geochemistry and Tetrad Effect of Some Muscovite Granites at Wadi El Gemal Area, South Eastern Desert, Egypt. Journal of Geoscience and Environment Protection, 10, 75-93. https://doi.org/10.4236/gep.2022.102006

Received: November 3, 2021

Accepted: February 22, 2022

Published: February 25, 2022

Copyright $\odot 2022$ by author(s) and Scientific Research Publishing Inc. This work is licensed under the Creative Commons Attribution International License (CC BY 4.0).

http://creativecommons.org/licenses/by/4.0/

\begin{abstract}
The muscovite granites at the study area are being emplaced into biotite granites and ophiolitic mélange settings. They occur in four exposures namely; Umm Seleimat, Sikait, Umm El Kheran and Umm Addebaa exposure. The presence of garnet and muscovite flakes may reflect the peraluminous nature of the studied muscovite granites. Petrographically, the studied granites are mostly subsolvus and consist of plagioclase, $\mathrm{K}$-feldspars, quartz, muscovite and biotite. Garnet, zircon, allanite and opaques are accessories. The textural features of these granites are expressed by bent plagioclase lamellae, distorted microcline twinning, deformed mica flakes and development of myrmekite and recrystallization of feldspars into fine-grained aggregates. Umm Seleimat and Sikait exposures are more differentiated due to the presence of high content of K-feldspar and LREEs. The REE budget decreased from Umm Seleimat-Sikait exposures to Umm El Kheran-Umm Addebaa exposures as (514.5 - 495.6) to (195.9 - 197.7), respectively. Umm Seleimat-Sikait exposures have lower HREE/LREE (0.12 - 0.67), relative to Umm El Kheran-Umm Addebaa exposures $(0.99-2.06)$. The studied granites revealed that the chondrite normalized REE patterns are the normal M-type of tetrad effect, where TE1,3 tetrad effect is higher than 1 in all samples which implies that there was an interaction between melt and water-haloid-rich fluid when these granites are crystallized from magma. Spectrometric values of Umm Seleimat and Umm Addebaa indicate that $\mathrm{U}$ content is more than Th content. Applying the $\mathrm{U}$ mobilization equation proved that the studied granites have been originated from a late magmatic phase of magma very rich in radioelements, also the majority of measurements lie above the zero line indicating that the studied granites affected with hydrothermal solutions rich in uranium than thorium which indicates uranium addition.
\end{abstract}




\section{Keywords}

Wadi El Gemal, Umm El Kheran, REE Geochemistry, Tetrad Effect, Egypt

\section{Introduction}

The study area is located between latitudes $24^{\circ} 39^{\prime} 18^{\prime \prime} \mathrm{N}$ and $24^{\circ} 34^{\prime} 30^{\prime \prime} \mathrm{N}$ and longitudes $34^{\circ} 47^{\prime} 42^{\prime \prime} \mathrm{E}$ and $34^{\circ} 53^{\prime} 43^{\prime \prime} \mathrm{E}$ (Figure 1) at about $52 \mathrm{~km}$, southwest of Marsa Alam coastal city. In Egypt, peraluminous leucogranites represent phases of late orogenic to an orogenic granite complex. They brought about Mo, Sn, W, $\mathrm{U}$, and $\mathrm{Nb}-\mathrm{Ta}$ mineralization in the form of stock works or in the quartz veins within the granitic rocks (Hassan et al., 1984; Takla \& Nowier, 1980). In geosciences, tetrad effect-like REE patterns are reported both in magmatic rocks and in precipitates from hydrothermal fluids (Masuda \& Ikeuchi, 1978; Masuda \& Akagi, 1990; Akagi et al., 1993; Lee et al., 1994; Kawabe, 1995; Akagi et al., 1996; Bau, 1996). Recent discussions about the tetrad effect focus on highly evolved igneous rocks (Bau, 1997; Pan, 1997), which are often interpreted as transitional between the end-members of magmatic and high-temperature hydrothermal systems (e.g., Bau, 1996; Irber \& Bau, 1995). The objective of this contribution is to examine if the intensity of the tetrad effect correlates with parameters that reflect the evolution of granitic melts. Additionally, a Rayleigh REE fractionation is calculated to examine whether mineral fractionation can cause the gradual evolution of the tetrad effect or not. In this paper, the author throws some light on the geology, petrography, REE geochemistry and radioactivity of some muscovite leucogranites at Wadi El Gemal area.

\section{Geologic Setting}

\subsection{Regional Geology}

The Migif-Hafafit metamorphic core complex represents one of three major domal structures in the Eastern Desert of Egypt: Gabal Meatiq (Loizenbauer et al., 2001), Abu Swayel (Abd El-Naby \& Frisch, 2002), and Migif-Hafafit area (Fowler \& El Kalioubi, 2002; Abd El-Naby et al., 2000). The geology of Hafafit area has been documented as highly complex, and many hypotheses have been proposed for the tectonic evolution of this area (Fowler \& Osman, 2001). The study area is a part of the Migif-Hafafit and Wadi Nugrus-Wadi El Gemal areas representing the geologic and tectonic key domains with great significance in the tectonic evolution of the Arabian Nubian Shield, which belongs to the Pan African events. The rock units along W. El Gemal differ in colors and tones, thus they easily to be recognized and delineated on a Landsat image (Figure 1(a)).

\subsection{Geology of the Study Area}

The rocks exposed in the study area (Figure 1(b)) are dominantly ophiolitic mélange (oldest), metagabbros, biotite granites that intruded by small-to-large 


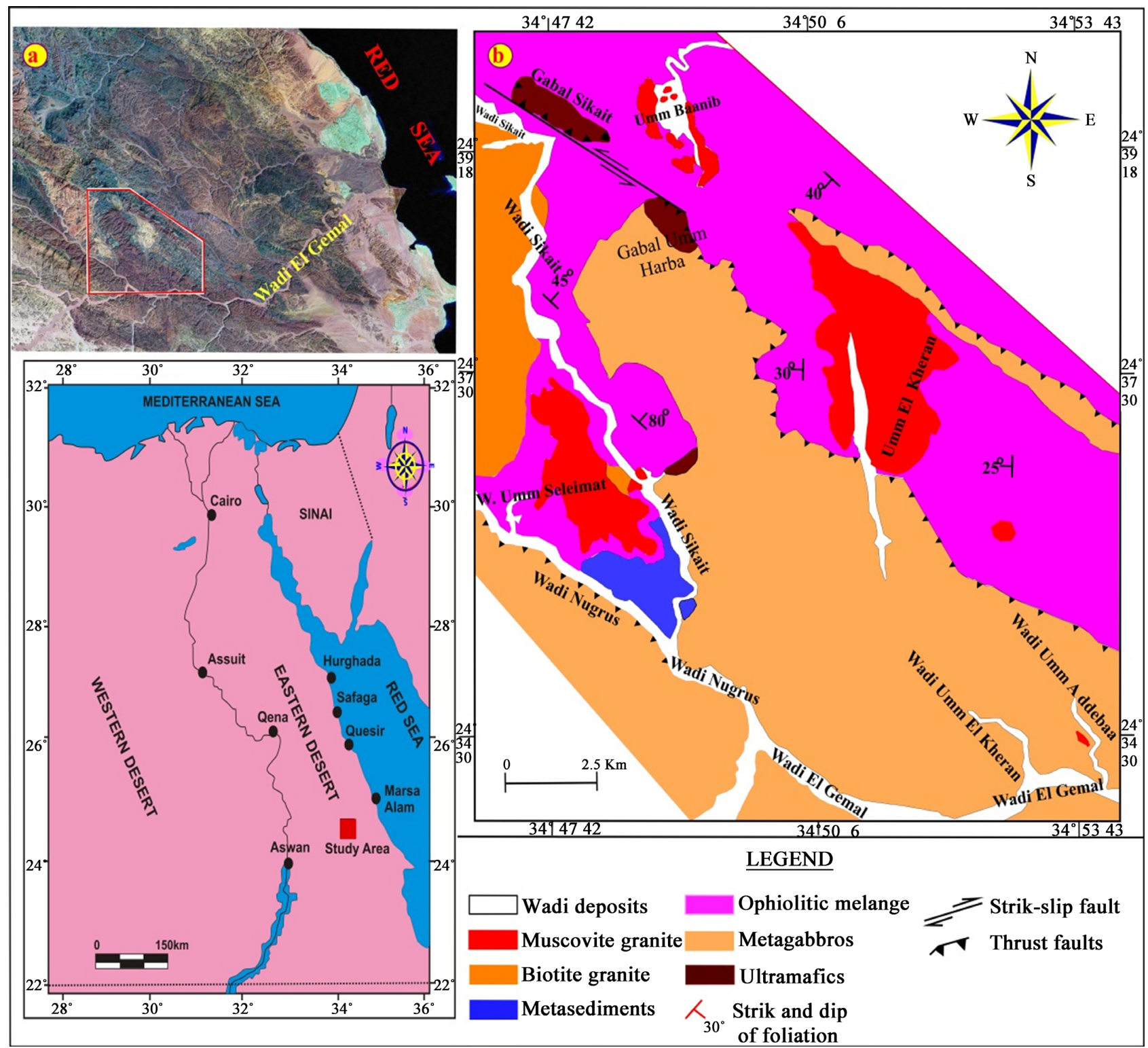

Figure 1. (a) Landsat image showing the different tons of rock units and location of the study area. (b) Regional geologic map of the study area, SED, Egypt, after Mahmoud, 2009.

bosses of muscovite granites with sharp contacts and post granite dikes and veins (youngest). No chilled margins are observed at the contact between the muscovite granites and their surroundings. These granites are localized in many exposures within this area namely; Umm Seleimat, Sikait, Umm El Kheran and Umm Addebaa exposures which considered a tributaries of W. Nugrus and W. El Gemal. 1) Umm Seleimat exposure: The muscovite granite at Umm Seleimat exposure is large in size $\left(>1.0 \mathrm{~km}^{2}\right)$ and emplaced along NW-SE trend, reaching about 1 $2 \mathrm{Km}$. in length and $200-300 \mathrm{~m}$ in width. It appears as small off-shoots of boss-like bodies, as dike-like bodies and a huge semicircular mass forms domal shape intrudes the biotite granites and the ophiolitic mélange (Figure 2(a)). It is characterized by white color, fine- to coarse-grained and occasionally pegmatitic. In some places, the 

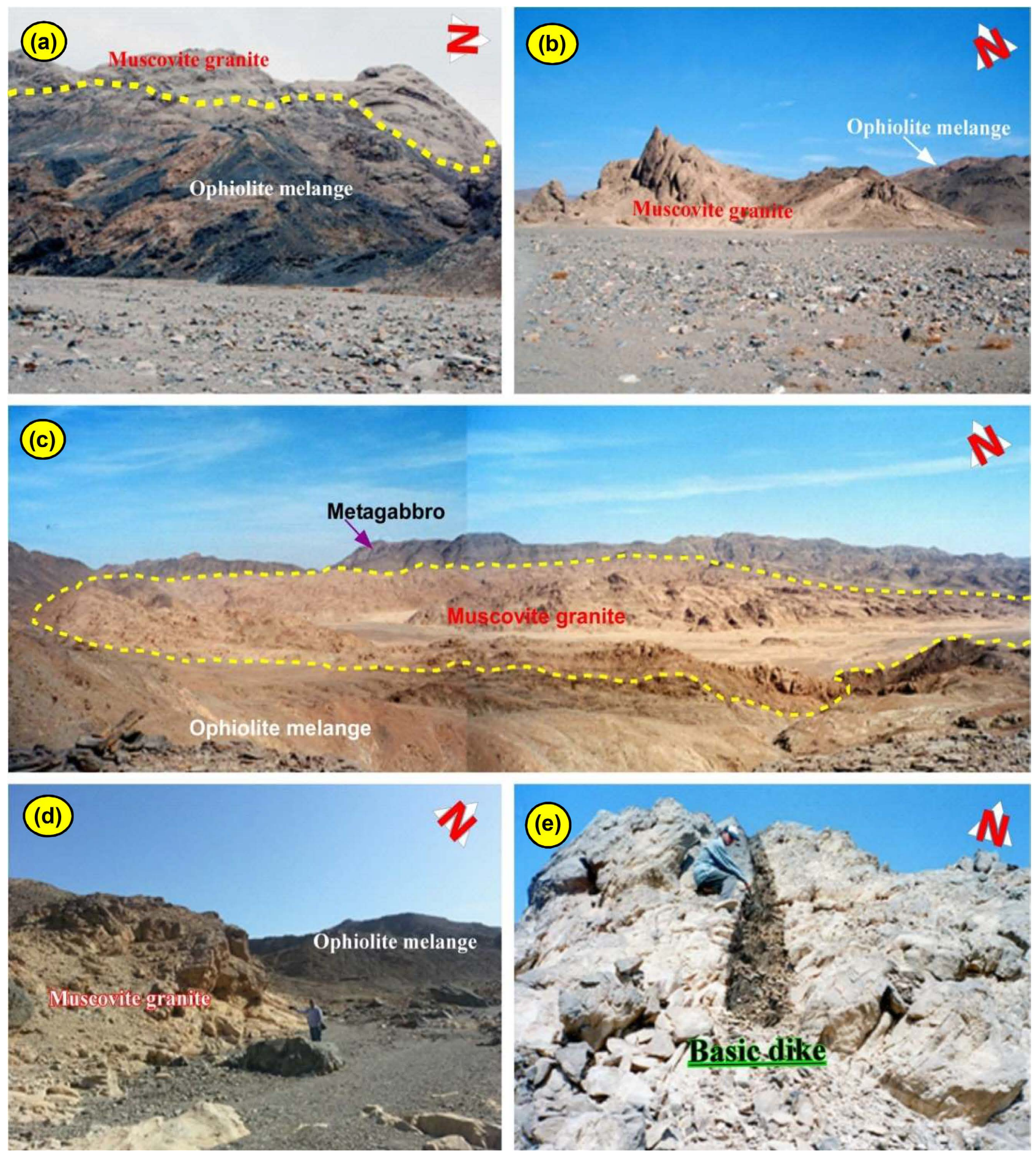

Figure 2. Field photographs showing: (a) Muscovite granite intrudes ophiolitic mélange with sharp contact at Umm Seleimat exposure. (b) Sharp peaks of muscovite granite at Sikait exposure. (c) Panoramic view showing the muscovite granite and its surroundings at Umm El Kheran exposure. (d) Dike-like body of muscovite granite intrudes ophiolitic mélange with sharp contact, at Umm Addebaa. (e) Basic dike cuts muscovite granite, at Umm Addebaa.

muscovite granite is highly deformed due to intensive tectonism. 2) Sikait exposures: the muscovite granites occur as masses or bosses with either rounded to elongated tops or even sharp peaks intruding the ophiolitic mélange which un- 
derwent high temperature-low pressure metamorphism (El Shazly \& Hassan, 1972; El Bayoumi \& Greiling, 1984) (Figure 2(b)). The studied granite at Sikait is small in size $\left(<1.0 \mathrm{~km}^{2}\right)$ and emplaced along NW-SE trend, reached about 300 - $400 \mathrm{~m}$. in length and $50-100 \mathrm{~m}$. in width. It is characterized by white color and grain size ranges between coarse-grained to coarse pegmatite. Pelitic rocks, mainly schists, are abundant as a matrix in the ophiolitic mélange. 3) Umm El Kheran exposure: the studied granite is located close to the major Nugrus thrust and appears as a huge semi-circular masse, form rounded and domal shapes within the high topography ridge of the metagabbro rocks intrudes in the ophiolitic mélange (Figure 2(c)). The granite of Umm El Kheran exposure is relatively large in size $\left(>1.0 \mathrm{~km}^{2}\right)$ emplaced along NW-SE trend, reached about 1.5 $2.5 \mathrm{~km}$. in length and $300-500 \mathrm{~m}$. in width, characterized by white color, coarse-grained and occasionally pegmatitic in some places. Two conjugate faults dissect the Umm El Kheran muscovite granite, NNW-and WNW with opposite sense of movements (left and right hand respectively) (Mahmoud, 2009). Metagabbros and talc-carbonates are the most common mafic-ultramafic fragments of the ophiolitic mélange at Umm El Kheran exposure. It has NW-SE foliation dipping due to NE direction with dip angle ranges from $60^{\circ}-70^{\circ}$. 4) Umm Addebaa exposure: it occurs as boss or dike-like body of the muscovite granite $\left(<1.0 \mathrm{~km}^{2}\right)$ emplaced along the N-S trend, about $100 \mathrm{~m}$. in length and $50 \mathrm{~m}$. in width intrudes in the ophiolitic mélange (Figure 2(d)). They are deformed and show well-known spheroidal weathering. The periphery, about $1 \mathrm{~m}$ wide, of the studied muscovite granite is characterized by presence of monomineralic bands of visible spessartine garnet. An NNW-SSE strike slip faults dislocate the muscovite granite pluton with common displacement. Some basic dikes (NNW-SSE) are cut through the muscovite granite (Figure 2(e)). The ophiolitic melange is characterized by high foliation striking NW-SE and dipping $\left(20^{\circ}-50^{\circ}\right)$ due to SW. Quartz-bearing beryl is present at Umm Addebaa exposure.

\section{Methodology}

Petrographical characteristics of the studied muscovite granites are examined in seventeen thin sections representing the muscovite granites in the four exposures. Fifteen of them [(4) from Umm Seleimat, (3) from Sikait, (4) from Umm El Kheran and (4) from Umm Addebaa], chemically analyzed for their rare earth elements by Induced Couple Plasma Spectrometer (ICP-OES) in the labs of Nuclear Materials Authority, Egypt. Analytical conditions were 1200 Watt R Watt RF current, $18 \mathrm{~L} / \mathrm{min}$. Coolant gas, $36 \mathrm{~L} / \mathrm{min}$. Neublizer gas pressure and 3 Replicant. The granitic samples were crushed and powdered in an agate mortar, 0.5 -g was digested by $10 \mathrm{ml}$ of $40 \%$ hydrofluoric acid (HF) and $5 \mathrm{ml}$ of $98 \%$ sulfuric acid $\left(\mathrm{H}_{2} \mathrm{SO}_{4}\right)$, it was heated at $200^{\circ} \mathrm{C}$ till dryness and it was dissolved in 10 $\mathrm{ml}$ of $20 \%$ hydrochloric acid $(\mathrm{HCl})$ the volume was completed to $50 \mathrm{ml}$ by ultra-pure water. $\mathrm{Na}_{2} \mathrm{CO}_{3}$ and $\mathrm{H}_{3} \mathrm{BO}_{4}$ for alkali flux were high grade (EDWIK) The 
standard solutions of REEs used for calibration were prepared in $4 \% \mathrm{HNO}_{3}$ diluted from $1000 \mathrm{ppm}$ standard solutions for atomic absorption spectrometry manufactured in Canada. Duplicate measurements provided a precision generally better than $2 \%$, except for $\mathrm{Er}$ and $\mathrm{Lu}(<3 \%)$. The accuracy of the analyses was monitored by a series of international reference materials. Based on the rock standard, accuracy was usually better than 5\%, except for La, $\operatorname{Er}(<10 \%)$, and $\operatorname{Pr}$ $(<30 \%)$. The detection limits for ICP-OES analyses are listed in Table 1.

Field ground $\gamma$-ray spectrometry survey has been done using $\gamma$-ray spectrometric multichannel analyzer instrument model RS-230 Canadian Type. Ground $\gamma$-ray spectrometric survey can detect dose rate (D.R.) in unit (nanosieverts per hour (nSvh-1)), potassium (K \%), equivalent uranium content (eU ppm), and equivalent thorium content (eTh ppm).

\section{Petrography}

Umm Seleimat muscovite granite is dominantly composed of quartz and feldspars (including plagioclase, microcline and perthite) in equal contents, muscovite and biotite. Garnet, allanite, zircon and iron oxides are common accessories. The abundant form of quartz is coarse-grained with more or less irregular boundaries. Plagioclase occurs as subhedral to euhedral tabular crystals of variable sizes exhibiting lamellar and albitic twining shows corrosional boundaries against perthite (Figure 3(a)). Microcline crystals with anhedral outlines distinguish by tartan or cross-hatched twinning (Figure 3(b)). Perthite is coarse and corroded by quartz. The muscovite occurs as subhedral flakes that are corroded by quartz (Figure 3(c)). Biotite shows a good cleavage and interference color from brown to green. Garnet occurs either as regular crystals, or as irregular crystals and skeletal forms, which are surrounded by quartz and biotite as inclusions (Figure 3(d)). Sikait muscovite granite is mainly composed of plagioclase, alkali feldspars, muscovite, biotite and quartz. Garnet, zircon, monazite and opaques are accessories. Plagioclase is represented by albite which occurs as subhedral crystals with high deformed and kinked lamellae (Figure 3(e)). Some crystals are granulated forming morter texture. Potash feldspars are mainly microcline perthite. Some crystals are strained and elongated forming fussy texture. Biotite is characterized by its anhedral shape with interference of color from green and brown (Figure 3(f)) with a good cleavage. Muscovite is common and occurs as tabular, isolated crystals. Garnet occurs either as euhedral polygonal crystals (Figure $3(\mathrm{~g})$ ) or as highly tectonically deformed subhedral to anhedral crystal. Zircon is found as euhedral crystals with color zonation included in plagioclase (Figure $3(\mathrm{~h})$ ). Monazite occurs as euhedral crystals included in quartz (Figure 3(i)). Umm El Kheran muscovite granite is medium to coarse-grained, showing hypidiomorphic equigranular texture. It is composed mainly of plagioclase, Quartz, rare K-feldspar, biotite and muscovite. Garnet, allanite and zircon are accessories. Fine-grained white mica aggregates and chlorite are secondary minerals. Myrmekitic texture is common. Plagioclase is the dominant feldspar in the 

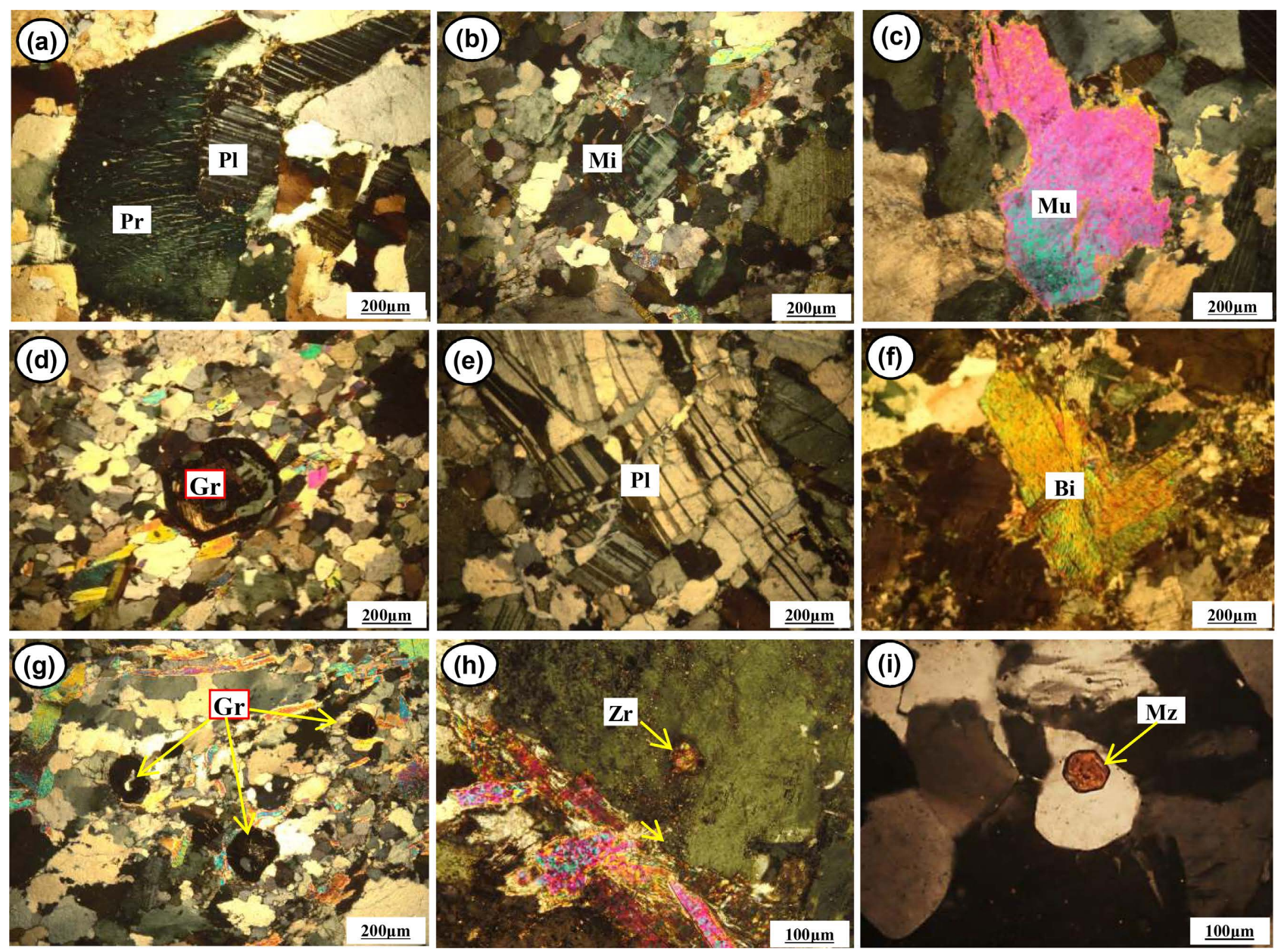

Figure 3. Photomicrographs of the studied muscovite granites of Umm Seleimat and Sikait exposures showing: (a) plagioclase crystal corroded by perthite, Umm Seleimat. (b) Subhedral crystal of microcline, Umm Seleimat. (c) Primary muscovite associating the feldspars and quartz, Umm Seleimat. (d) Secondary garnet (Gt) with relics of mica and silica, Umm Seleimat. (e) Highly deformed and dislocated plagioclase crystal, Sikait. (f) Flakes of biotite, Sikait. (g) Euhedral polygonal garnet crystals associating quartz, plagioclase, biotite and muscovite, Sikait. (h) Fine crystal of zircon included in plagioclase and associating muscovite, Sikait. (i) Monazite crystal included in quartz, Sikait. Abbreviations, Plagioclase (Pl), Perthite (Pr), Microcline (Mi), Biotite (Bi), Muscovite (Mu), Garnet (Gr), Zircon (Zr), Monazite (Mz).

rock occurs as tabular cloudy crystals with albite and percline twinning (Figure 4(a)) and exhibit wide range of grain sizes and generally corroded by quartz; along their boundaries a myrmekitic texture was observed (Figure 4(b)). The presence of myrmekitic texture represents strong evidence for metasomatic origin, which are common in magmatic granite (Smith, 1974). Microcline perthite is observed in subordinate amount as anhedral megacrysts showing the characteristic cross-hatched or tartan pattern, as a result of albite and percline twins' combination (Deer et al., 1992). Biotite and muscovite occur as fine-to medium-grained in both xenomorphic and subhedral flakes (Figure 4(c)). Umm Addebaa muscovite granite is coarse-grained and mainly composed of plagioclase, quartz, K-feldspar, muscovite and biotite. Plagioclase is dominant than K-feldspar. Fine-grained white mica aggregates and chlorite are secondary minerals, while, zircon, garnet and tourmaline are common as accessory minerals. 

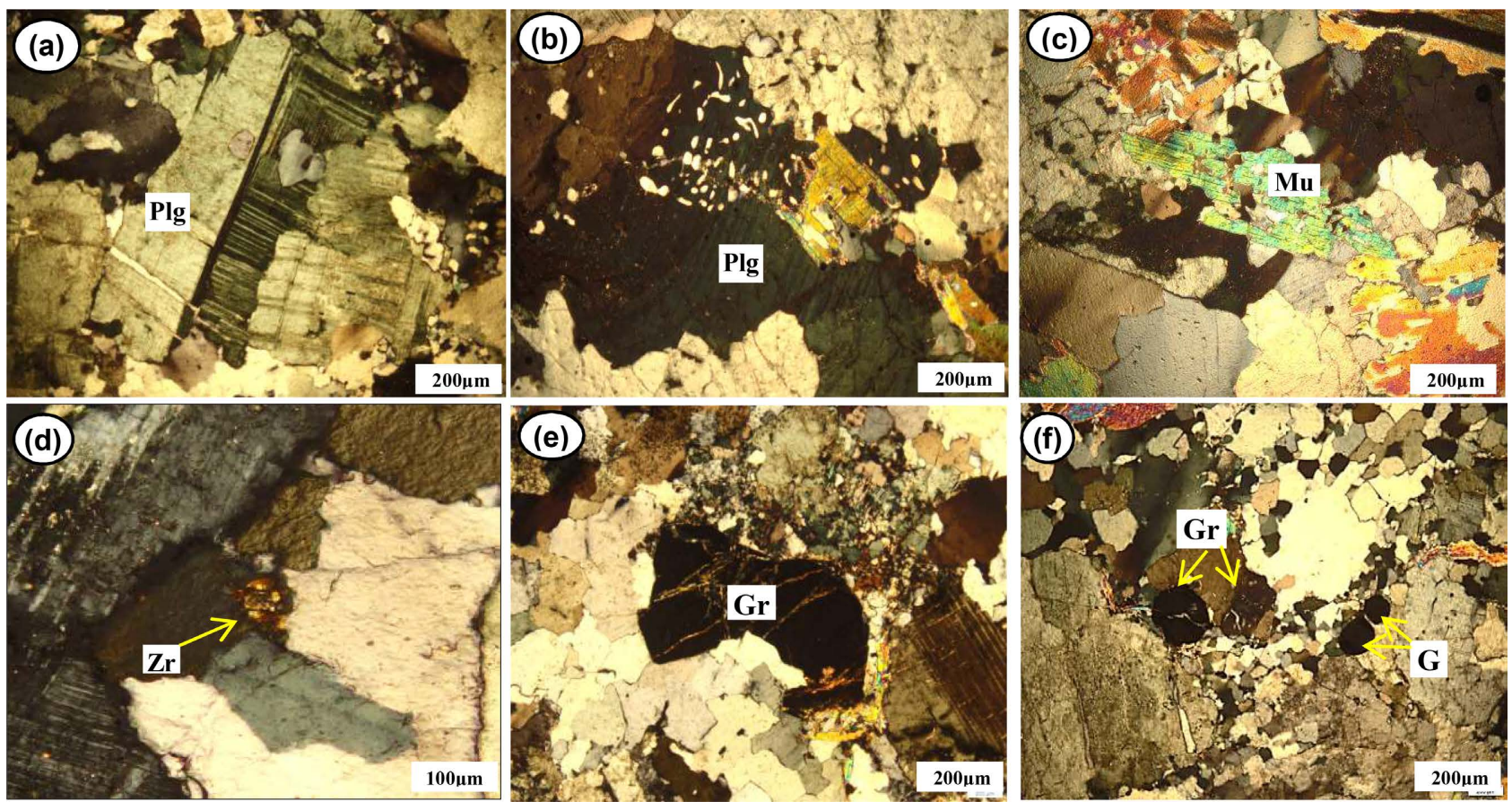

Figure 4. Photomicrographs of the studied muscovite granites of Umm El Kheran and Umm Addebaa exposures showing: (a) Plagioclase crystal with percline twinning, Umm El Kheran. (b) Myrmekitic texture of plagioclase, Umm El Kheran. (c) Muscovite corroded by quartz, Umm El Kheran. (d) Metamict zircon crystal associating quartz and plagioclase, Umm Addebaa. (e) Highly tectonically subhedral to anhedral crystals of garnet, Umm Addebaa. (f) Polygonal garnet crystal associating plagioclase and quartz, Umm Addebaa. Abbreviations, Plagioclase (Pl), Muscovite (Mu), Zircon (Zr), Garnet (Gr).

Myrmekitic texture is common. Plagioclase is represented by albite which occurs as subhedral to anhedral crystals with slight deformation (Figure 4(d)). Quartz occurs in appreciable amount as anhedral crystals, corroding all the preceding minerals. Muscovite is present in considerable amounts, although it is most common mica in the studied granite. Garnet; occurs as large oriented irregular crystals with pale pinkish color in plane polarized light, which appears in cracked or polygonal form (Figure 4(e) \& Figure 4(f)).

From petrographical point of view, the author classified the four exposures of the muscovite granites in the study area into two exposures as: Umm Seleimat-Sikait exposure and Umm El Kheran-Umm Addebaa exposure. Umm Seleimat-Sikait exposure is characterized by fine to pegmatitic granularity with high k-feldspar content and highly sheared and deformed rocks, while Umm El Kheran-Umm Addebaa exposure is characterized by fine- to coarse-granularity with low k-feldspar content and weak sheared rocks.

\section{REE Geochemistry and Tetrad Effect}

\section{Discussion}

The geochemistry of the rare earth elements (REEs) has been found that the behavior of the REEs in most geological environments can be accounted for by differences in their ionic radii (increasing contraction of the $5 \mathrm{~s}$ and $5 \mathrm{p}$ electron shells with increasing atomic mass) as well as variations in valence states $\left(\mathrm{Ce}^{+3}\right.$ or 
$\mathrm{Ce}^{+4}, \mathrm{Eu}^{+2}$ or $\left.\mathrm{Eu}^{+3}\right)$. However, an additional feature in the distribution patterns of the REEs is the tetrad effect. It refers to the subdivision of the 15 lanthanide elements into four groups in a chondrite normalized distribution pattern: 1) La-Ce-Pr-Nd, 2) Pm-Sm-Eu-Gd, 3) Tb-Dy-Ho, and 4) Er-Tm-Yb-Lu, and each group forms a smooth convex (M-type) or concave (W-type) pattern (Masuda et al., 1987).

$$
t_{1}=\left(\frac{C e}{C e^{t}} \times \frac{\operatorname{Pr}}{\operatorname{Pr}^{t}}\right) 0.5 \quad t_{3}=\left(\frac{T b}{T b^{t}} \times \frac{D y}{D y^{t}}\right) 0.5
$$

Degree of the tetrad effect TE1,3 $=\left(t_{1} \times t_{3}\right)^{0.5}$.

An REE pattern that does not show a tetrad effect has values of TE $1.3<1.1$. The M-shaped pattern shows TEi $>1.1$ and the $\mathrm{W}$-shaped TEi $<0.9$.

The REE tetrad effect is most visible in late magmatic differentiates with strong hydrothermal interactions or deuteric alteration. Moreover, the tetrad effect is often accompanied by other modified geochemical behavior of many trace elements, which is termed by Bau (1996) as non-CHARAC behavior (CHARAC $=$ Charge-and-Radius-Controlled). Such behavior occurs typically in highly evolved magmatic systems enriched in $\mathrm{H}_{2} \mathrm{O}, \mathrm{CO}_{2}$ and elements such as $\mathrm{Li}, \mathrm{B}, \mathrm{F}$ and/or $\mathrm{Cl}$, which suggests the increasing importance of an aqueous like fluid system during the final stages of granite crystallization (Bau, 1996; Irber, 1999). The modern advanced studies indicate that the REE budget of the hydrothermal fluids can be mobilized under particular conditions at metasomatic alteration (Michard, 1989). The REE mobility is controlled by $\mathrm{pH}$, high water/rock ratios, and abundant complex ions $\mathrm{CO}_{3}^{2-}, \mathrm{F}^{-}, \mathrm{Cl}^{-}, \mathrm{PO}_{4}^{2-}$, and $\mathrm{SO}_{4}^{2-}$ (Hass et al. 1995). The kinked pattern which is the characteristic REE tetrad effect, according to Masuda et al. (1987), extraction of a coexisting fluid from a peraluminous melt would result in both of the M-shaped and W-shaped REE tetrad effect, the former of which would be shown in the residual melt phase and the latter of which shown in the fluid. However, this corresponding relationship for a magma system has not been observed in the natural environment. Recently, it has been argued that peraluminous magmatic systems represent the transition from a silicate melt to a high-temperature hydrothermal system, and thus, the geochemical behavior of the isovalent incompatible elements in highly evolved granitic rocks are controlled mainly by chemical complexation with a variety of ligands (Bau \& Dulski, 1999; Bau, 1996, 1997; Dostal \& Chatterjee, 2000). Therefore, the origin of the REE tetrad effect was ascribed to the interaction between fluorine bearing fluid and silicate melt phases. Monecke et al. (2002), proposed that the tetrad effect might have formed within the magma fluid system before emplacement in the subvolcanic environment where phase separation caused a split of this system into fluid and magma subsystems, or that the tetrad effect might also be inherited from an external fluid influencing the system during or after the emplacement of the magma. Takahashi et al. (2002) recently found both Wand M-type tetrad effect in REE patterns for the water-rock systems in the Tono uranium deposit, central Japan, which is interpreted as that the preference of the 
groundwater for a W-type tetrad effect produces an M-type tetrad effect in the granitic rocks during weathering processes. It is important to notice that the reported cases are $\mathrm{M}$ - or $\mathrm{W}$-type tetrad effects occurring separately in natural systems, however, the composite M- and W-type REE tetrad effect were firstly reported by Zhao et al. (2008). Thus, our study is important step in understanding the REE tetrad effect. The kinks in the REE patterns are camouflaged by prominent convex and concave tetrads and pronounced negative to slightly positive $\mathrm{Eu}$ anomalies. The second tetrad is comparably difficult to recognize due to the anomalous behavior of $\mathrm{Eu}$ and the fact that $\mathrm{Pm}$ does not occur in nature.

\section{Results}

In the granites studied the concentrations of REEs are determined. The analytical results of REE contents of whole rocks are listed in Table 1 and plotted on the chondrite-normalized REE patterns are shown in Figure 5 \& Figure 6. The concentration of any given REE in any given rock has proved useful to normalize with standard reference materials. This is appropriate when using graphical plots for REE data. The chondrite normalized patterns in (Figure 5) are reflected the characters of the solutions which effected in the original rocks. The REE budget decreased from Umm Seleimat-Sikait exposures to Umm El Kheran-Umm Addebaa exposures as (514.5 - 495.6) to (195.9 - 197.7), respectively, as in Table 1.

The muscovite granites of Umm Seleimat-Sikait exposures are characterized by LREEs (average 363.4 - $418.6 \mathrm{ppm}$ ) higher than HREEs (151.2 - $76.9 \mathrm{ppm}$ ) while the muscovite granites of Umm El Kheran-Umm Addebaa exposures characterized by LREEs (average $87-83.1 \mathrm{ppm}$ ) lower than HREEs (109 - 114.6 $\mathrm{ppm})$ (Table 1$)$, reflected in $(\mathrm{La} / \mathrm{Lu}) \mathrm{n}$ values from 0.53 to 1.2 . This likely reflects preferential depletion of LREE elements by fractionation of accessory phases such as monazite (Mittlefehldt \& Miller, 1983) or attributed to the presence of the garnet, which is an excellent host for HREE. Umm Seleimat-Sikait exposures have lower HREE/LREE (0.12 - 0.67), relative to Umm El Kheran-Umm Addebaa exposures $(0.99$ - 2.06). The REE patterns show strongly negative Eu anomalies

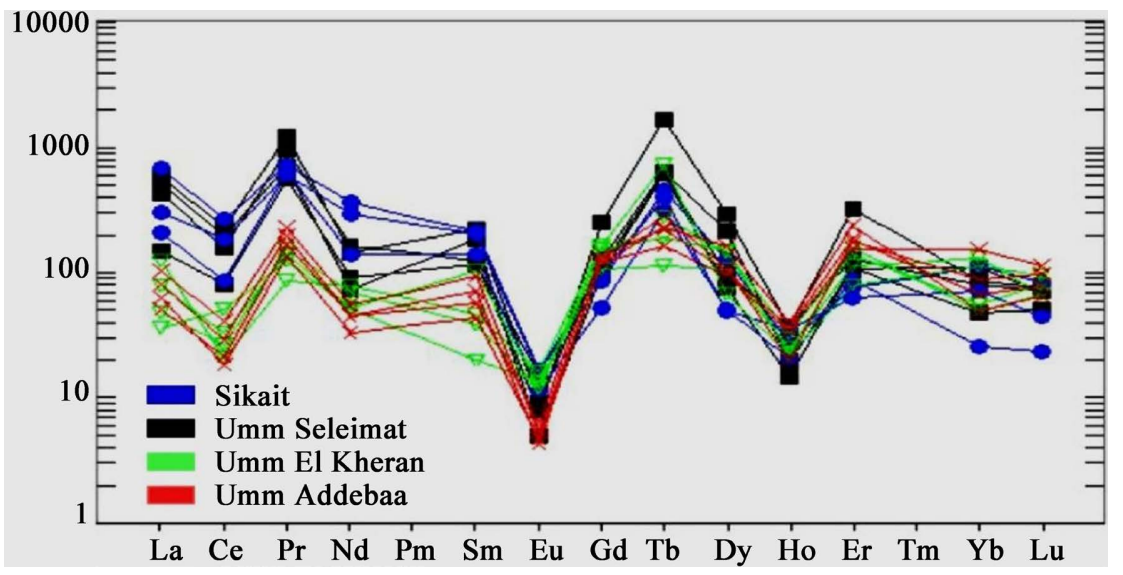

Figure 5. Chondrite normalized REE pattern of the studied granitic rocks. The contents of REE are normalized to the composition of C1 chondrites (Sun \& McDonough, 1989). 
Table 1. REE contents of the studied muscovite granites (ppm).

\begin{tabular}{|c|c|c|c|c|c|c|c|c|c|c|c|c|c|c|c|c|}
\hline \multirow{2}{*}{ Sample } & \multicolumn{4}{|c|}{ Umm Seleimat } & \multicolumn{3}{|c|}{ Sikait } & \multicolumn{4}{|c|}{ Umm El Kheran } & \multicolumn{4}{|c|}{ Umm Addebaa } & \multirow{2}{*}{$\begin{array}{l}\text { Det. } \\
\text { Limit } \\
\text { (ppb) }\end{array}$} \\
\hline & Sm1 & $\mathrm{Sm} 2$ & $\mathrm{Sm} 3$ & $\mathrm{Sm} 4$ & S1 & S2 & S3 & Kh1 & $\mathrm{Kh} 2$ & Kh3 & Kh4 & D1 & D2 & D3 & D4 & \\
\hline $\mathrm{La}$ & 123.1 & 138.54 & 101.22 & 35.87 & 158.75 & 73.01 & 49.65 & 18.4 & 8.6 & 11.3 & 29.01 & 12.01 & 19.06 & 24.12 & 15.1 & 50.0 \\
\hline $\mathrm{Ce}$ & 119.87 & 140.24 & 97.64 & 49.84 & 164.2 & 113.72 & 52.62 & 20.13 & 31.2 & 16.4 & 12.5 & 13.04 & 17.76 & 25.3 & 11.23 & 50.0 \\
\hline $\operatorname{Pr}$ & 67.42 & 114.5 & 89.8 & 53.31 & 67.98 & 56.21 & 60.86 & 13.37 & 11.93 & 14.72 & 8.12 & 16.07 & 18.85 & 21.9 & 13.03 & 30.0 \\
\hline $\mathrm{Nd}$ & 33.76 & 66.74 & 77.56 & 42.41 & 169.52 & 137.1 & 64.75 & 24.5 & 23.68 & 32.4 & 36.47 & 20.63 & 21.03 & 25.85 & 15.34 & 50.0 \\
\hline Sm & 28.45 & 33.86 & 19.02 & 18.05 & 32.65 & 31.06 & 21.34 & 15.94 & 3.02 & 5.9 & 7.16 & 8.72 & 10.96 & 14.19 & 6.72 & 30.0 \\
\hline $\mathrm{Eu}$ & 0.29 & 0.53 & 0.46 & 0.9 & 0.97 & 0.93 & 0.66 & 0.71 & 0.773 & 0.684 & 0.939 & 0.37 & 0.25 & 0.31 & 0.27 & 20.0 \\
\hline Gd & 20.12 & 26.46 & 52 & 22.86 & 19.72 & 17.48 & 10.82 & 32.02 & 21.66 & 27.88 & 33.64 & 28.58 & 25.95 & 24.4 & 24.8 & 20.0 \\
\hline $\mathrm{Tb}$ & 22.95 & 23.61 & 61.86 & 22.97 & 14.89 & 16.9 & 11.77 & 7.11 & 4.2 & 10.24 & 26.77 & 8.31 & 10.6 & 6.1 & 8.52 & 20.0 \\
\hline Dy & 24.8 & 55.63 & 74.22 & 19.03 & 12.48 & 32.38 & 12.68 & 37.78 & 27.12 & 36.68 & 16.92 & 25.96 & 27.78 & 23.65 & 42.21 & 20.0 \\
\hline Ho & 2.12 & 1.099 & 2.01 & 0.839 & 1.99 & 1.56 & 1.18 & 1.29 & 1.42 & 1.87 & 1.25 & 2.01 & 1.13 & 1.91 & 2.22 & 10.0 \\
\hline Er & 21 & 17.79 & 53.25 & 17.91 & 10.56 & 12.38 & 14.56 & 26.07 & 18.55 & 23.1 & 13.12 & 30.7 & 29.34 & 25.47 & 39 & 10.0 \\
\hline $\mathrm{Yb}$ & 13.81 & 18.6 & 14.68 & 8.11 & 12.24 & 19.03 & 4.33 & 8.48 & 22.48 & 9.32 & 19.2 & 11.37 & 14.98 & 26.12 & 8.45 & 10.0 \\
\hline $\mathrm{Lu}$ & 1.82 & 1.83 & 1.95 & 1.3 & 1.13 & 2.1 & 0.6 & 1.68 & 1.68 & 2.03 & 2.4 & 1.96 & 2.5 & 2.85 & 1.66 & 5.0 \\
\hline$\Sigma$ HREE & 106.6 & 145.1 & 259.9 & 93.1 & 73.01 & 101.8 & 55.9 & 114.4 & 97.11 & 111.1 & 113.3 & 108.9 & 112.3 & 110.5 & 126.86 & - \\
\hline ¿LREE & 372.9 & 494.4 & 385.7 & 200.4 & 594.1 & 412.03 & 249.8 & 93.05 & 79.2 & 81.4 & 94.2 & 70.84 & 87.9 & 111.7 & 61.69 & - \\
\hline Total REEs & 479.5 & 639.4 & 645.7 & 293.4 & 667.08 & 513.9 & 305.8 & 207.5 & 176.3 & 192.5 & 207.5 & 179.7 & 200.2 & 222.2 & 188.6 & - \\
\hline Average & \multicolumn{4}{|c|}{514.5} & \multicolumn{3}{|c|}{495.6} & \multicolumn{4}{|c|}{195.9} & \multicolumn{4}{|c|}{197.7} & - \\
\hline HREE/LREE & 0.28 & 0.29 & 0.67 & 0.46 & 0.12 & 0.25 & 0.22 & 1.23 & 1.23 & 1.36 & 1.20 & 1.54 & 1.28 & 0.99 & 2.06 & - \\
\hline $\mathrm{Eu} / \mathrm{Eu}^{*}$ & 0.04 & 0.05 & 0.04 & 0.14 & 0.12 & 0.12 & 0.13 & 0.10 & 0.29 & 0.16 & 0.18 & 0.07 & 0.05 & 0.05 & 0.06 & - \\
\hline$(\mathrm{La} / \mathrm{Sm})_{\mathrm{N}}$ & 2.70 & 2.56 & 3.32 & 1.24 & 3.04 & 1.47 & 1.45 & 0.72 & 1.78 & 1.20 & 2.53 & 0.86 & 1.09 & 1.06 & 1.40 & - \\
\hline$(\mathrm{La} / \mathrm{Lu})_{\mathrm{N}}$ & 7.02 & 7.86 & 5.39 & 2.86 & 14.58 & 3.61 & 8.59 & 1.14 & 0.53 & 0.58 & 1.25 & 0.64 & 0.79 & 0.88 & 0.94 & - \\
\hline$(\mathrm{La} / \mathrm{Yb})_{\mathrm{N}}$ & 6.06 & 5.06 & 4.68 & 3.00 & 8.81 & 2.61 & 7.79 & 1.47 & 0.26 & 0.82 & 1.03 & 0.72 & 0.86 & 0.63 & 1.21 & - \\
\hline $\mathrm{T} 1$ & 1.92 & 1.82 & 1.46 & 1.82 & 0.89 & 1.10 & 1.38 & 1.07 & 1.87 & 1.12 & 0.43 & 1.27 & 1.26 & 1.30 & 1.10 & - \\
\hline $\mathrm{T} 3$ & 4.04 & 7.43 & 7.33 & 5.28 & 2.41 & 4.96 & 3.78 & 2.82 & 2.13 & 2.97 & 3.63 & 2.14 & 3.51 & 1.95 & 2.83 & - \\
\hline $\mathrm{T} 1,3$ & 2.79 & 3.68 & 3.27 & 3.10 & 1.46 & 2.34 & 2.28 & 1.73 & 1.99 & 1.82 & 1.25 & 1.65 & 2.10 & 1.59 & 1.76 & - \\
\hline
\end{tabular}

The TE 1,3 are calculated by the formulae of Irber (1999).

$\left(\mathrm{Eu} / \mathrm{Eu}^{*} 0.04-0.2\right)$; this finding suggests extensive fractionation of feldspar. The normalized REE patterns of the studied granites show elevated ( $\mathrm{Pr})$, (Tb, Dy), and $(\mathrm{Tm}, \mathrm{Yb})$ relative to the neighboring REE, which may be a weak expression of the tetrad effect (Irber, 1999). This effect is typical of transitional magmatic-hydrothermal systems and is often found in highly evolved, volatile-rich granites (Monecke et al., 2002). According to Jahn et al. (2001), it is unlikely that mineral fractionation alone could generate the tetrad effect in evolved granites. Rather, they emphasized the increasing importance of exchange with aqueous 
fluid during the final stages of granite crystallization. Figure 5 \& Figure 6 show that samples of the studied granites have strong M-type tetrad effect in the first and third tetrad. The index of tetrad effect intensity, TE1,3 is higher than 1 in all samples which implies that there was an interaction between melt and water-haloid-rich fluid when these granites are crystallized from magma.

Therefore, such REE fractionation during evolution, enrichment by accessory minerals and alteration can be interpreted to be the breakdown of accessory minerals and the formation of new minerals (Peterson \& Eliasson 1997; Hecht et al., 1999). The ratio $\mathrm{La}_{\mathrm{N}} / \mathrm{Yb}_{\mathrm{N}}$ is considered by Rollinson (1994) as a measure of the degree of fractionation of REEs in the melt. Plotting of the same ratio versus CeN showed that; Umm Seleimat and Sikait exposures are more differentiated than Umm El Kheran and Umm Addebaa exposures, referring to increasing of degree of fractionation with increasing of the LREE represented by Ce (Figure 7).

\section{Spectrometric Investigations}

Discussion: Rogers and Adams (1969) stated that the average content of eU in granite is $4 \mathrm{ppm}$ and that of Th is $16 \mathrm{ppm}$. Moreover, Darnely (1982) defined the uraniferous granites as any granitic mass containing $\mathrm{eU}$ at least twice as Clark value $(4 \mathrm{ppm})$ for normal granites. Such granites may or may not be associated with eU-mineralization. Uranium mobilization $(\mathrm{eUm})$ in the studied
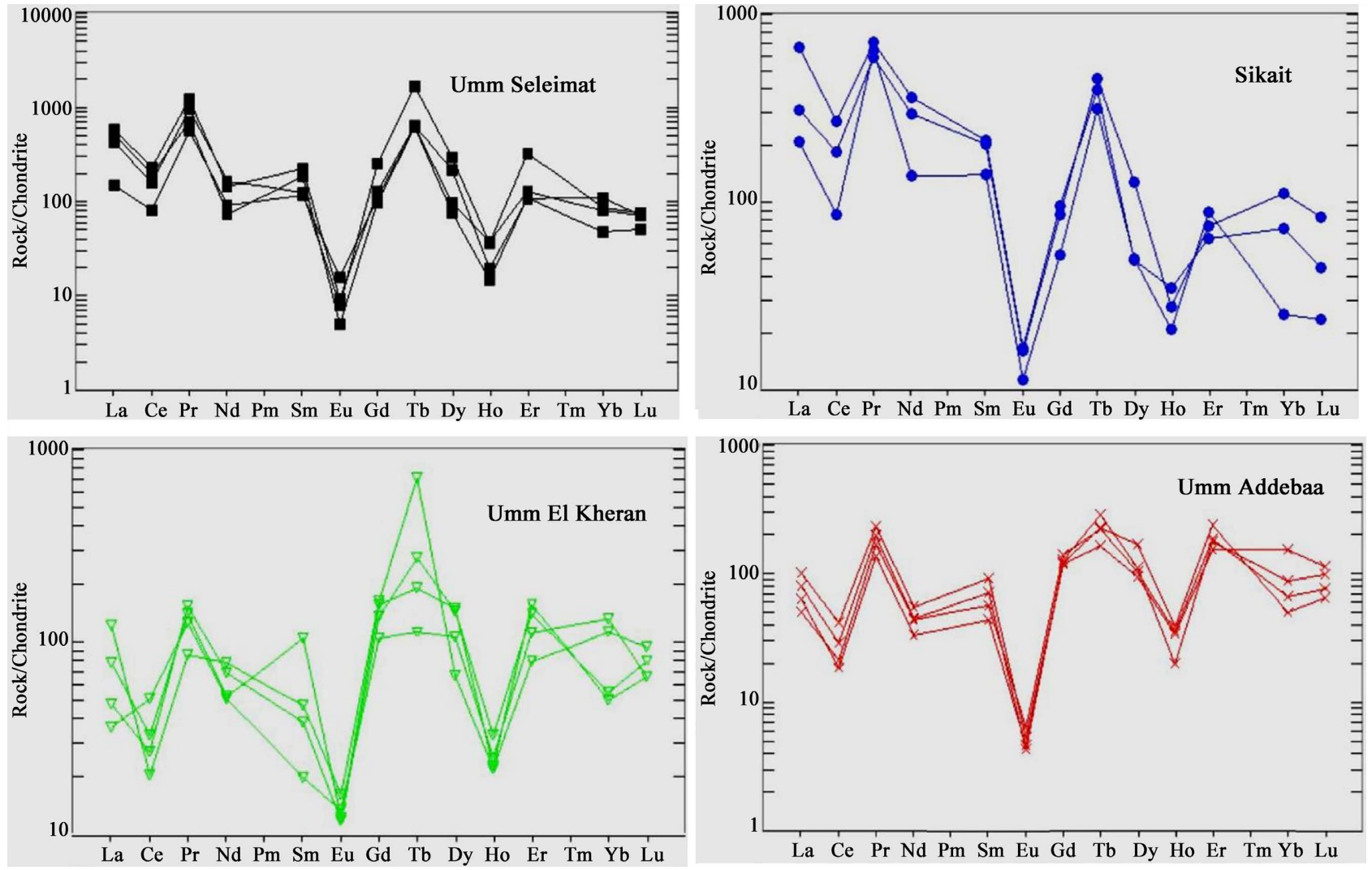

Figure 6. Chondrite normalized REE pattern of the studied granitic rocks. The contents of REE are normalized to the composition of C1 chondrites (Sun \& McDonough, 1989). 
rocks can be calculated as follows: the uranium mobilization is calculated difference between the measured $\mathrm{eU}$ and the expected original uranium, which is calculated by dividing the measured eTh by the average eTh/eU ratio in the crustal acidic rocks (original uranium $=\mathrm{eTh} / 3.5$ according to Clark et al., 1966) to give the leaching values of uranium $(e U m=e U-e T h / 3.5)$. Positive values indicate uranium addition by mobilization, whereas negative values indicated migration of uranium by leaching. The eU, eTh, K\% and other variants in all studied granitic rocks are illustrated in Table 2. Some ratios were also calculated (eTh/eU and eU/eTh).

Results: eU and eTh data of the studied granites of the present study when compared with the published data indicates that these granites can be described as uraniferous granite except granite of the Sikait area considered as not uraniferous where the average $U$ content is less than twice as Clark value (4 ppm). The spectrometric values of Umm Seleimat and Umm Addebaa indicate that $U$ content is more than Th content. Uranium content is more than twice Clark value (4 ppm), while eTh content is too less than Clark value (18- $20 \mathrm{ppm})$ suggesting that they are fertile granites.

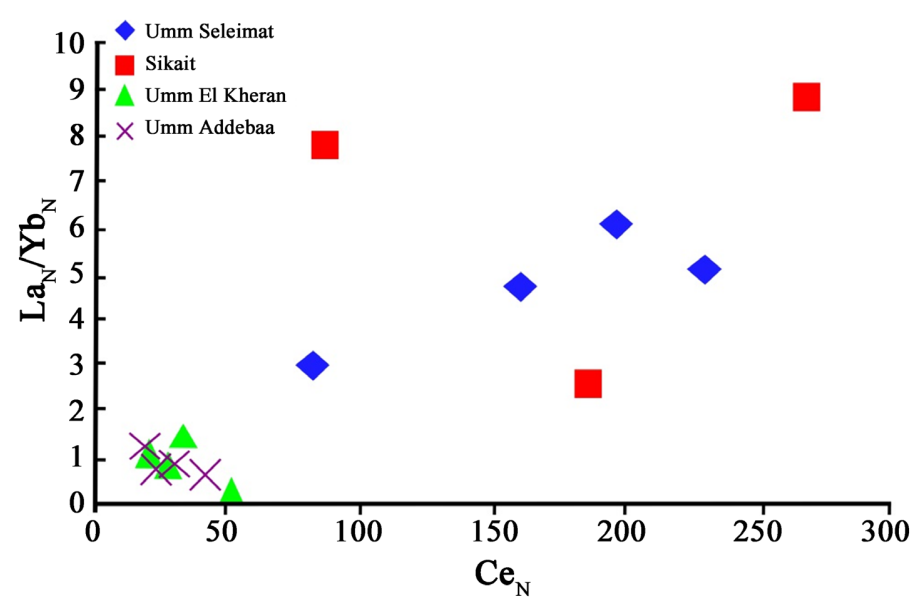

Figure 7. Degree of fractionation vs $\mathrm{Ce}_{\mathrm{N}}$ of the studied granites.

Table 2. Field spectrometric analysis of the range and average contents of eU, eTh, and $\mathrm{K} \%$ of the studied muscovite granites, SED, Egypt.

\begin{tabular}{|c|c|c|c|c|c|c|c|c|c|c|}
\hline \multirow{2}{*}{ The study areas } & \multicolumn{2}{|c|}{$\mathrm{eU}(\mathrm{ppm})$} & \multicolumn{2}{|c|}{ eTh (ppm) } & \multicolumn{2}{|c|}{$\mathrm{eU} / \mathrm{eTh}$} & \multicolumn{2}{|c|}{$\mathrm{eTh} / \mathrm{eU}$} & \multicolumn{2}{|c|}{$(\mathrm{K} \%)$} \\
\hline & Range & Av. & Range & Av. & Range & Av. & Range & Av. & Range & Av. \\
\hline Umm Seleimat $(\mathrm{n}=17)$ & $4.5-41.8$ & 21.4 & $6-28.5$ & 15.73 & $0.5-2.3$ & 1.3 & $0.4-1.8$ & 1.04 & $2.6-5.9$ & 3.9 \\
\hline Sikait $(\mathrm{n}=15)$ & $2.7-5.1$ & 4.3 & $1.3-7.7$ & 3.2 & $0.4-2.8$ & 1.7 & $0.3-2.1$ & 0.8 & $2.4-7.8$ & 5.5 \\
\hline Umm El Kheran $(\mathrm{n}=12)$ & $2.9-11.5$ & 6.9 & $3.2-15$ & 9.5 & $0.3-0.8$ & 0.6 & $1.2-2.9$ & 1.6 & $2.8-4.9$ & 3.9 \\
\hline Umm Addebaa $(n=15)$ & $4.9-15.7$ & 10.5 & $1.5-6.9$ & 4.2 & $1.5-6.5$ & 2.7 & $0.2-0.6$ & 0.4 & $1.4-3.9$ & 2.8 \\
\hline Adams et al., 1959; Clarke et.al., 1966 & $1-9$ & 4 & $18-20$ & 19 & 0.33 & 0.25 & - & - & - & - \\
\hline $\begin{array}{l}\text { Crustal acidic igneous rocks (after } \\
\text { IAEA, } 1979 \text { and Boyle, 1982). }\end{array}$ & $1-12$ & 4.5 & $5-20$ & 18 & $0.1-0.5$ & 0.25 & - & - & - & 4 \\
\hline
\end{tabular}



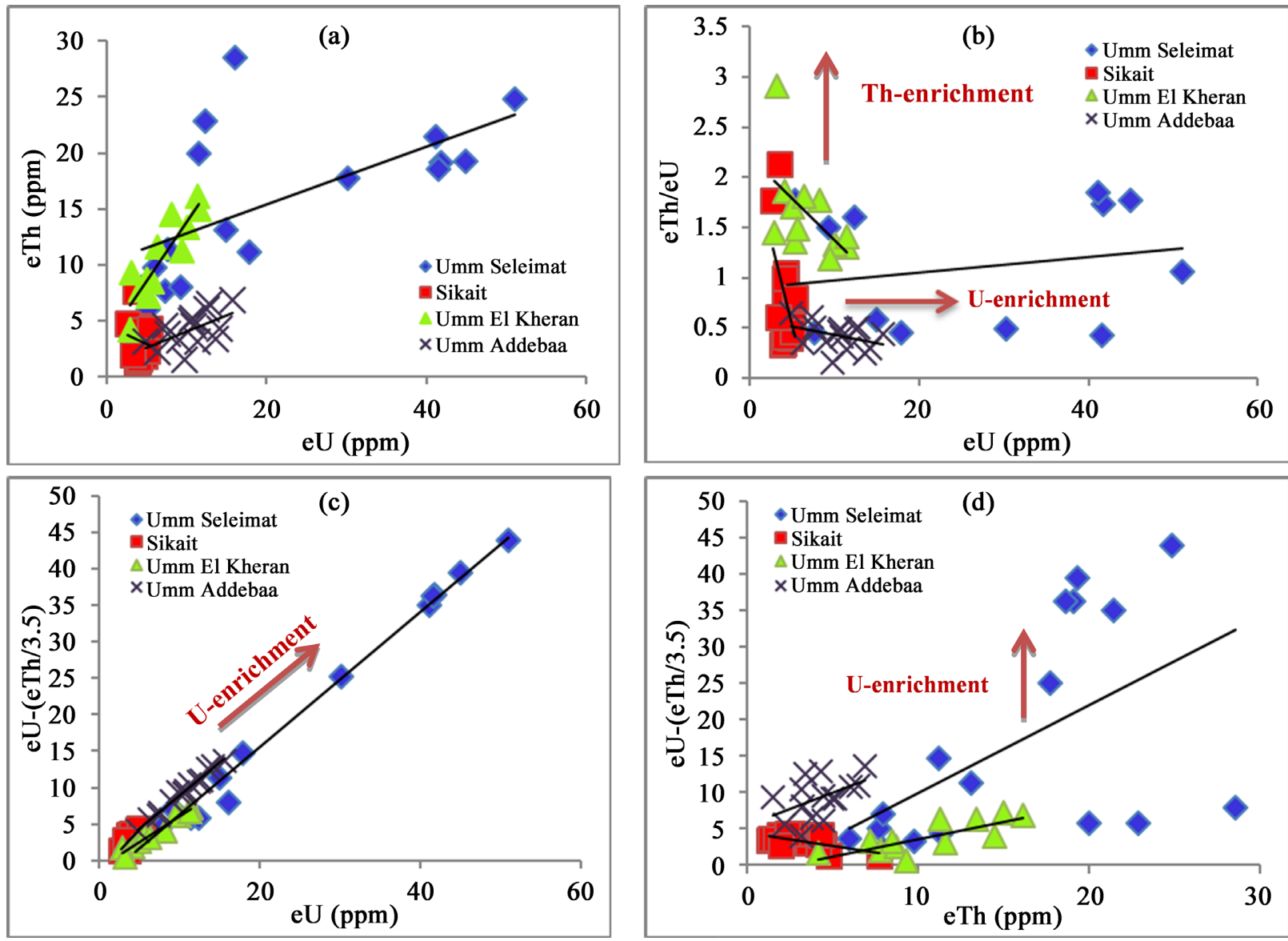

Figure 8. Radioelement plots for the studied muscovite granites.

The binary relations of $\mathrm{eU}, \mathrm{eTh}$, and $\mathrm{eTh} / \mathrm{eU}$ may provide an indicator of the geochemical behavior of $U$ and $T h$ in the studied granitic samples. The plot of $\mathrm{eU}$ versus eTh illustrates that there are very strong positive relations between the variants in all of the rocks indicating their magmatic origin (Figure 8(a)). The eTh/eU ratio versus eU diagram Figure 8(b) shows that Umm Seleimat and Umm Addebaa samples show indirect relation reflect the uranium enrichment is strong where the eU content of Umm Seleimat ranges between 4.5 and $42.8 \mathrm{ppm}$ with an average of $21.4 \mathrm{ppm}$, and the eTh content ranges between 6 and 28.5 ppm with an average of $51.73 \mathrm{ppm}$, whereas eU content of Umm Addebaa ranges between 4.9 and $15.7 \mathrm{ppm}$ with an average of $10.5 \mathrm{ppm}$, and the eTh content ranges between 1.5 and $6.9 \mathrm{ppm}$ with an average of 4.2, while Sikait and Umm El Kheran samples, uranium has a narrow range of values.

Result of the equation eU-(eTh/3.5) revealed that some of the measurements lie near the zero line, and this means that these samples have been originated from a late magmatic phase of magma very rich in radioelements with uranium concentration more than thorium. On the other side, the majority of measurements lie above the zero line indicating that the granites affected with hydrothermal solutions rich in uranium than thorium which indicates uranium addition (Figure 8(c) \& Figure 8(d)). 


\section{Conclusions}

1) The study area at Wadi El Gemal area consists mainly of ophiolitic mélange, cataclastic rocks, biotite granites and muscovite leucogranites. The studied muscovite granites are exposed in four exposures namely: Umm Seleimat, Sikait, Umm El Kheran and Umm Addebaa that belong to the younger granites of the Pan African rock units.

2) The muscovite leucogranites were intruded through the ophiolitic mélange and biotite granites with sharp contacts paralleling to the foliations of metasediments of ophiolitic mélange along the thurst fault.

3) Petrographically, muscovite granites are composed mainly of quartz, plagioclase of albitic composition, potash feldspar and muscovite. Monazite, zircon, allanite, garnet and opaques are accessory minerals. The presence of two feldspars suggests that the studied muscovite granites are mostly subsolvus and crystallized under high water pressure (Greenberg, 1981; Deer et al., 1992). Also, the presence of bent, kinked and gliding of plagioclase lamellae as well as high cracking and strongly undulatory quartz, all these features point to subsolidus deformation (Paterson et al., 1989). Such deformation should be the result of extensive regional thrusting (Greiling et al., 1987), to which the area had been subjected.

4) The REE compositions of the muscovite granites were determined using ICP-OES analytical method, the REE budget decreased from Umm Seleimat-Sikait exposures to Umm El Kheran-Umm Addebaa exposures as (514.5 495.6) to (195.9 - 197.7), respectively and the results consistently show the tetrad effect.

5) Similar M-type REE tetrad effect and strong Eu depletion are observed in whole-rock granitic samples. Consequently, the tetrad effect represents the integrated behavior of the entire members (=individual phases) of the rocks. The REE tetrad effect is accompanied by strong Eu negative anomalies.

6) Highly fractional crystallization leads to the enrichment of volatile, alkaline, rare earth elements and rare metals in residual melts which may result in a co-existing magmatic-hydrothermal system. The fluid/melt interaction in this system produces the REE tetrad effect in the melt and in the rock-forming and accessory minerals crystallizing from this melt. The minerals inherited the REE composition and distribution characteristics of the melt. Therefore, the interaction between granitic melt and coexisting volatile-rich fluid is the most important factor controlling the formation of REE tetrad effects in the studied muscovite granites.

7) Spectrometric investigation using binary diagrams revealed that the distribution of uranium and thorium in the studied granites increases gradually from Sikait, umm El Kheran, Umm Addebaa to Umm Seleimat. The binary relations of eU, eTh, and eTh/eU for all granitic exposures show strong positive relations exist with $U$ and Th indicating their magmatic origin. Meanwhile, the result of mobilization equation proved that the studied granites samples have been origi- 
nated from a late magmatic phase of magma very rich in radioelements.

\section{Conflicts of Interest}

The author declares no conflicts of interest regarding the publication of this paper.

\section{References}

Abd El-Naby, H. H., \& Frisch, W. (2002). Origin of the Wadi Haimur-Abu Swayel Gneiss Belt, South Eastern Desert, Egypt: Petrological and Geochronological Constraints. Precambrian Research, 113, 307-322. https://doi.org/10.1016/S0301-9268(01)00214-5

Abd El-Naby, H. H., Frisch, W., \& Hegner, E. (2000). Evolution of Pan-African Wadi Haimur Metamorphic Sole, Eastern Desert, Egypt. Journal of Metamorphic Geology, 18, 639-651. https://doi.org/10.1046/j.1525-1314.2000.00286.x

Adams, J. A. S., Osmond, Y. K., \& Rogers, J. J. W. (1959). The Geochemistry of Thorium and Uranium. Physics and Chemistry of the Earth, 3, 298-348. https://doi.org/10.1016/0079-1946(59)90008-4

Akagi, T., Nakai, S., Shimiuzu, H., \& Masuda, A. (1996). Constraints on the Geochemical Stage Causing Tetrad Effect in Kimuraite: Comparative Studies on Kimuraite and Its Related Rocks, from REE Pattern and Nd Isotope Ratio. Geochemical Journal, 30, 139-148. https://doi.org/10.2343/geochemj.30.139

Akagi, T., Shabani, M. B., \& Masuda, A. (1993). Lanthanide Tetrad Effect in Kimuraite $\left[\mathrm{CaY}_{2}\left(\mathrm{CO}_{3}\right)_{4} \cdot 6 \mathrm{H}_{2} \mathrm{O}\right]$ : Implication for an New Geochemical Index. Geochimica et Cos mochimica Acta, 57, 2899-2905. https://doi.org/10.1016/0016-7037(93)90397-F

Bau, M. (1996). Controls on the Fractionation of Isovalent Trace Elements in Magmatic and Aqueous Systems: Evidence from $\mathrm{Y} / \mathrm{Ho}, \mathrm{Zr} / \mathrm{Hf}$, and Lanthanide Tetrad Effect. Contributions to Mineralogy and Petrology, 123, 323-333. https://doi.org/10.1007/s004100050159

Bau, M. (1997). The Lanthanide Tetrad Effect in Highly Evolved Felsic Igneous Rocks-A Reply to the Comment by Y. Pan. Contributions to Mineralogy and Petrology, 128, 409-412. https://doi.org/10.1007/s004100050318

Bau, M., \& Dulski, P. (1999). Comparing Yttrium and Rare Earths in Hydrthermal Fluid from Mid-Atlantic Ridge: Implications for Y and REE Behaviour during Near-Vent Mixing and for the Y/Ho Ratio of Proterozoic Seawater. Chemical Geology, 155, 77-90. https://doi.org/10.1016/S0009-2541(98)00142-9

Boyle, R. W. (1982). Geochemical Prospecting for Thorium and Uranium Deposits (p. 489). Elsevier.

Clarke, S. P. J., Peterman, Z. E., \& Heier, K. S. (1966). Abundances of Uranium, Thorium and Potassium. In Handbook of Physical Constants (pp. 521-541). Geological Society of America Memoirs. https://doi.org/10.1130/MEM97-p521

Darnely, A. G. (1982). "Hot” Granites: Some General Remarks. In Y. T. Maurice (Ed.), Uranium in Granites. Geological Survey of Canada Paper No. 81-23 (pp. 1-10). Government of Canada. https://doi.org/10.4095/111365

Deer, W. A., Howie, R. A., \& Zussman, J. (1992). An Introduction to the Rock-Forming Minerals (2nd ed.). Longman Group Limited.

Dostal, J., \& Chatterjee, A. K. (2000). Contrasting Behavior of Nb/Ta and Zr/Hf Ratios in a Peraluminous Granitic Pluton (Nova Scotia, Canada). Chemical Geology, 163, 207-218. 
https://doi.org/10.1016/S0009-2541(99)00113-8

El Bayoumi, R. M. A., \& Greiling, R. (1984). Tectonic Evolution of a Pan-African Plate Margin in South-Eastern Egypt-A Suture Zone Overprinted by Low Angle Thrusting? In J. Klerkx, \& J. Michot (Eds.), African Geology (pp. 47-56). African Geology Journal.

El-Shazly, E. M., \& Hassan, M. A. (1972). Geology and Radioactive Mineralization at Wadi Sikait-Wadi El Gemal Area, South Eastern Desert. Egyptian Journal of Geology, 16, 201-234.

Fowler, A. R., \& El Kalioubi, B. (2002). The Migif-Hafafit Gneissic Complex of the Egyptian Eastern Desert: Fold Interference Patterns Involving Multiply Deformed Sheath Folds. Tectonophysics, 346, 247-275. https://doi.org/10.1016/S0040-1951(01)00259-1

Fowler, T. J., \& Osman, A. F. (2001). Gneiss-Cored Interference Dome Associated with Two Phases of Late Pan-African Thrusting in the Central Eastern Desert, Egypt. Precambrian Research, 108, 17-43. https://doi.org/10.1016/S0301-9268(00)00146-7

Greenberg, J. K. (1981). Characteristics and Origin of Egyptian Younger Granites: Summary. GSA Bulletin, 92, 224-256. https://doi.org/10.1130/0016-7606(1981)92\%3C224:CAOOEY\%3E2.0.CO;2

Greiling, R. O., Kroner, A., El Ramly, M. F., \& Rashwan, A. A. (1987). Structural Relationships between the Southern and Central Parts of the Eastern Desert of Egypt: Details of a Fold and Thrust Belt. In S. El Gaby, \& R. O. Greiling (Eds.), The Pan-African Belt of Northeast Africa and Adjacent Areas (pp. 121-146). Vieweg Verlag.

Haas, J. R., Shock, E. L., \& Sassani, D. C. (1995). Rare Earth Elements in Hydrothermal Systems: Estimates of Standard Partial Molal Thermodynamic Properties of Aqueous Complexes of the Rare Earth Elements at High Pressures And Temperatures. Geochimica et Cosmochimica Acta, 59, 4329 \pm 4350 . https://doi.org/10.1016/0016-7037(95)00314-P

Hassan, M., El-Bakry, H., Al-Amin, E., \& Al Bassiony, Q. (1984). Geochemical Orientation Survey of Tungsten Mineralization in Arid Conditions, Eastern Desert, Egypt. Bulletin of Faculty of Science, Zagazig University, 6, 38-54.

Hecht, L., Thuro, K., Plinninger, R., \& Cuney, M. (1999). Mineralogical and Geochemical Characteristics of Hydrothermal Alteration and Episyenitization in the Königshain Granites, Northern Bohemian Massif, Germany. International Journal of Earth Sciences, 88, 236-252. https://doi.org/10.1007/s005310050262

International Atomic Energy Ageney (IAEA) (1979). Gamma Ray Surveys in Uranium Exploration. Technical Report Series, Paper No. 186, 90 p.

Irber, W. (1999). The Lanthanide Tetrad Effect and its Correlation with K/Rb, Eu/Eu*, $\mathrm{Sr} / \mathrm{Eu}, \mathrm{Y} / \mathrm{Ho}$ and $\mathrm{Zr} / \mathrm{Hf}$ of Evolving Peraluminous Granite Suits. Geochimica et Cosmochimica Acta, 63, 489-508. https://doi.org/10.1016/S0016-7037(99)00027-7

Irber, W., \& Bau, M. (1995). Fractionation of Zr/Hf, Y/Ho and the REEs (Tetrad Effect) and Its Significance as a Geochemical Tool for Characterization of Granite Evolution. Beih. 1 Eur. J. Mineral, 7, 112.

Jahn, B. M., Wu, F. Y., Capdevila, R., Martineau, F., Zhao, Z., \& Wang, Y. (2001). Highly Evolved Juvenile Granites with Tetrad REE Patterns: The Woduhe and Baerzhe Granite from the Great Xing'an Mountains in NE China. Lithos, 59, 171-198.

https://doi.org/10.1016/S0024-4937(01)00066-4

Kawabe, I. (1995). Tetrad Effects and Fine Structures of REE Abundance Patterns of Granitic and Rhyolitic Rocks: ICP-AES Determinations of REE and Y in Eight GSJ Reference Rocks. Geochemical Journal, 29, 213-230.

https://doi.org/10.2343/geochemj.29.213 
Lee, S. G., Masuda, A., \& Kim, H. S. (1994). An Early Proterozoic Leuco-Granitic Gneiss with the REE Tetrad Phenomenon. Chemical Geology, 114, 59-67. https://doi.org/10.1016/0009-2541(94)90041-8

Loizenbauer, J., Wallbrecher, E., Fritz, H., Neumayr, P., Khudeir, A. A., \& Kloetzli, U. (2001). Structural Geology, Single Zircon Ages and Fluid Inclusion Studies of the Meatiq Metamorphic Core Complex: Implications for Neoproterozoic Tectonics in the Eastern Desert of Egypt. Precambrian Research, 110, 357-383.

https://doi.org/10.1016/S0301-9268(01)00176-0

Mahmoud, A. M. (2009). Highlight on the Geology, Geochemistry and Spectrometry of the Muscovite Granites at Wadi El Gemal Area, South Eastern Desert, Egypt. Ph.D. Thesis, Faculty of Science, Suezcanal University.

Masuda, A., \& Akagi, T. (1990). Lanthanide Tetrad Effect Observed in Leucogranites from China. Geochemical Journal, 23, 245-253.

https://doi.org/10.2343/geochemj.23.245

Masuda, A., \& Ikeuchi, Y. (1978). Lanthanide Tetrad Effect Observed in Marine Environment. Geochemical Journal, 13, 19-22. https://doi.org/10.2343/geochemj.13.19

Masuda, A., Kawakami, O., Dohmoto, Y., \& Takenaka, T. (1987). Lanthanide Tetrad Effects in Nature: Two Mutually Opposite Types, W and M. Geochemical Journal, 21, 119-124. https://doi.org/10.2343/geochemj.21.119

Michard, A. (1989). Rare Earth Element Systematic in Hydrothermal Fluids. Geochimica et Cosmochimica Acta, 53, 745-750. https://doi.org/10.1016/0016-7037(89)90017-3

Mittlefehldt, D. W., \& Miller, C. F. (1983). Geochemistry of the Sweetwater Wash Pluton, California: Implications for "Anomalous" Trace Element Behaviour during Differentiation of Felsic Magmas. Geochimica et Cosmochimica Acta, 47, 109-124. https://doi.org/10.1016/0016-7037(83)90095-9

Monecke, T., Kempe, U., Monecke, J., Sala, M., \& Wolf, D. (2002). Tetrad Effect in Rare Earth Element Distribution Patterns: A Method of Quantification with Application to Rock and Mineral Samples from Granite-Related Rare Metal Deposits. Geochimica et Cosmochimica Acta, 66, 1185-1196. https://doi.org/10.1016/S0016-7037(01)00849-3

Pan, Y. M. (1997). Controls on the Fractionation of Isovalent Trace Elements in Magmatic and Aqueous Systems: Evidence from Y/Ho, Zr/Hf, and Lanthanide Tetrad Effect ĐA Discussion of the Article by M. Bau (1996). Contributions to Mineralogy and Petrology, 128, 405-408. https://doi.org/10.1007/s004100050317

Paterson, S. R., Vernon, R. H., \& Tobisch, O. H. (1989). A Review of Criteria for the Identification of Magmatic and Tectonic Foliations in Granitoids. Journal of Structural Geology, 11, 349-363. https://doi.org/10.1016/0191-8141(89)90074-6

Peterson, J., \& Eliasson, T. (1997). Mineral Evolution and Element Mobility during Episyenitization (Dequartzification) and Albitization in the Postkinematic Bohus Granite Southwest Sweden. Lithos, 42, 123-146. https://doi.org/10.1016/S0024-4937(97)00040-6

Rogers, J. W., \& Adams, J. S. S. (1969). Uranium. In K. H. Wedepohl (Ed.), Handbook of Geochemistry(Vol. 4, pp. 92 B1-92 C10). New York: Springer-Verlag.

Rollinson, H. R. (1994). Using Geochemical Data: Evaluation, Presentation and Interpretation. Singapore: Longman Scientific \& Technical, 352 p.

Smith, P. J. (1974). Ophiolites and Oceanic Lithosphere. Nature, 250, 99-100. https://doi.org/10.1038/250099a0

Sun, S. S., \& McDonough, W. F. (1989). Chemical and Isotope Systematics of Oceanic Basalts: Implications for Mantle Composition and Processes. In A. D. Sunders, \& M. J. Norry (Eds.), Magmatism in the Ocean Basins (pp. 313-345). Geological Society Special 
Publication. https://doi.org/10.1144/GSL.SP.1989.042.01.19

Takahashi, Y., Yoshida, H., Sato, N., Hama, K., Yusa, Y., \& Shimizu, H. (2002). W- and M-Type Tetrad Effects in REE Patterns for Water-Rock Systems in the Tono Uranium Deposit, Central Japan. Chemical Geology, 184, 311-335. https://doi.org/10.1016/S0009-2541(01)00388-6

Takla, M. A., \& Nowier, A, M. (1980). Mineralogy and Mineral Chemistry of the Ultramafic Mass of El-Rubshi, Eastern Desert, Egypt. Neues Jahrbuch für Mineralogie Abhandlungen, 140, 17-28.

Zhao, Z. H., Bao, Z. W., \& Lee, S. G. (2008). A Composite M- with W-Type of REE Tetrad Effect in a North China Alkaline Complex. Geochimica et Cosmochimica Acta, 72, Article ID: 11095. 